\title{
Perceived Organizational Support as a Mediator of Managerial Coaching Skills and Occupational Commitment
}

\author{
Min-Hsun Christine Kuo ${ }^{1}$, Yuhsuan Chang $^{2}$ \& Wan Chieh Chang ${ }^{3}$ \\ ${ }^{1}$ Graduate Institute of HRM, National Central University, Chungli, Taiwan \\ ${ }^{2}$ College of Management, Yuan Ze University, Chungli, Taiwan \\ ${ }^{3}$ Graduate Institute of HRM, National Central University, Chungli, Taiwan \\ Correspondence: Min-Hsun Christine Kuo, Graduate Institute of HRM, National Central University, Chungli, \\ Taiwan. Tel: 886-3-422-7151 (ext.66767). E-mail: ckinyzu@gmail.com
}

Received: October 24, 2013 Accepted: November 19, 2013 Online Published: April 29, 2014

doi:10.5539/par.v3n1p17 URL: http://dx.doi.org/10.5539/par.v3n1p17

\begin{abstract}
Career development is becoming an important issue for all employees. Employees must assume greater responsibility for their own career development, become more adaptive, be able to handle ambiguity, and be more resilient when facing career challenges. Because of unpredictable working environments, employee commitment may shift from organization commitment to occupational commitment. Based on an analysis of 209 employees, this study concludes that managerial coaching skills are significantly associated with occupational commitment. In addition, perceived organizational support has a fully mediated effect on affective and normative occupational commitment, but no positive relationship with employee's accumulated costs and limited alternatives occupational commitment. This paper helps classify the effects of managerial coaching skills on employees. By improving managerial coaching skills, managers can help their employees excel in their occupation.
\end{abstract}

Keywords: managerial coaching skills, organizational support, occupational commitment

\section{Introduction}

Today's organizations face numerous challenges, including downsizing, rightsizing, flattening, becoming a learning organization, and so on. Unpredictable occupational environments have implications on career development in the future (Schein, 1996). Because of insecurity in the working environment, employees may distrust an organization, therefore, organizations sustain talents by developing talents (Yarnall, 1998).

Johnson (1996) indicated that employment commitment may shift from organization commitment to occupation commitment. Employees are now changing to careers based on self-direction in the pursuit of psychological fulfillment (as cited in Hall, 1995). Behavioral scientists generally focus on individual development topics, such as career choice (Brown \& Lent, 1996), career development (Hall, 1976), career mobility (Sicherman \& Galor, 1990), professional, and occupational commitment (Meyer, Allen, \& Smith, 1993). Regarding career development research, which is also a component of human resource development (HRD) (Gilley, Eggland, \& Gilley, 2002; McLagan, 1989), an occupation is a major life constituency that revolves around work, which provides a sense of purpose, challenge, and self-fulfillment. In addition, work is a source of identity that promotes status and provides access to social networking (Baruch, 2004). Yet, Colarelli and Bishop (1990) argued that occupational commitment is important in career development, and they also found that employees who had a mentor could present strong career commitment.

Occupational commitment can be defined as an individual's commitment to his or her occupation with affective reactions as well as psychological identify to a given occupation (Lee, Carswell, \& Allen, 2000). That is, an individual with strong occupational commitment tend to possess positive emotions about one's choice of occupation. Occupational commitment has been linked to several benefits for organizations. For example, committed employees tend to have better attention on the job, longer working tenure, and also work harder than employees with weak commitment. Regarding the effect of supervisor or manager effectiveness on employee occupational commitment, Kram (1983) suggested that manager and subordinates could perform career and psychological functions that enable young adults to overcome the challenges of work. 
Kidd and Smewing (2001) suggested that future research should clarify the influence of types of supervision support on the employees' occupational outcomes. Leaders should learn to be a coach, not a boss. (Stowell, 1988). People who have coaching skills can provide support to enhance employee skills, provide resources to improve self-knowledge and promote a sense of life balance that helps subordinates change, and build commitment to self-development and achievement (Vries, Guillén, Korotov, \& Treacy, 2010). Yet, Goleman (2000) argued that manager's coaching skills are still not fully exercised by organizations.

Although coaching techniques are often practiced in business, the literature presents only a few reliable coaching scales (Ellinger, Ellinger, \& Keller, 2003). Further understanding on the influence of manager's coaching skills in combination with perceived organizational support on career development outcomes is the motivation of this study. Previous research suggests that organization and supervisor support from the work environment influence employee attitudes, perceptions, and development activities (Kozlowski \& Hults, 1987). Support from the work environment or organization, such as valuing individual contribution, or providing opportunities and rewards, can improve employee's career motivation (London, 1983). However, Noe and Ford (1992) argued the need for additional research on perceptual information, such as supportiveness from an organization for personal development.

This study examines the effects of managerial coaching skills and perceived organizational support on occupational commitment. This study examines variables at the level of individual perception, including managerial coaching skills, occupational commitment, and perceived organizational support. To our knowledge, there have been very limited studies addressing the above constructs in current research. Most of occupational commitment studies have focused on related constructs of job satisfaction, turnover intention, but very few has examined the effect of coaching skills. Therefore, we expected that the results of this study will contribute to human resource development both conceptually and practically. Conceptually, this study extends the current knowledge in the human resource development field based on a non-traditional HRD theory, which offers innovative perspectives for examining these three constructs. Moreover, the theoretical relationships among managerial coaching skills, perceived organizational support, and occupational commitment can be clarified. The results of this study can contribute to identifying HRD practices that may facilitate employees' occupational commitment. Development programs for coaching skills can play a vital role in communicating the needs of employees by providing further organizational support. We expected to establish the foundation for future research and theory on managerial coaching and occupational commitment in HRD disciplines.

\subsection{Managerial Coaching Skills}

Managerial coaching has received considerable attention as a novel method of leadership in organizations (McGill \& Slocum, 1998; McLean \& Kuo, 2000; McLean et al., 2005). One series of studies focuses on managers or leaders as coaches (Orth, Wilknson \& Benfari, 1987; Stowell, 1988; Evered \& Selman, 1989; Geber 1992; Graham, Wedman, \& Kester, 1994; Ellinger, Ellinger \& Keller, 2005; Hamlin, Ellinger, \& Beattie, 2006). And, many empirical studies on managerial coaching have been conducted in recent years (Redshaw, 2000; Ellinger, Ellinger, \& Keller, 2003; Hamlin, Ellinger, \& Beattie, 2009; Hagen, 2012). Ellinger et al. (2005) conducted a survey on 438 warehouse workers and 67 warehouse supervisors, and found that a supervisor's coaching behaviors are positively associated with warehouse workers' job satisfaction and work-related performance. Hunt and Weintraub (2002) indicated that business leaders and managers who identify themselves as 'coaching managers' tend to help their employees learn and develop through a coaching process.

Managers who are most effective at developing employees incorporate the skill of coaching into their management style (Orth et al., 1987). It is noted that managerial coaching is viewed as a skill set that can be developed. Research shows that leaders who are like coaches focus on personal development; leaders express belief in their employees, expect their best efforts, help employees meet challenges wholeheartedly, and increase their commitment to work (Goleman, 2000).

McLean, Yang, Kuo, Tolbert, and Larkin (2005) developed an instrument to measure managerial coaching skills. McLean et al. (2005) defined coaching as a "set of managerial skills that demonstrates effective coaching characteristics in terms of open communicating with others, taking a team approach to tasks, valuing people over tasks, and accepting the ambiguous nature of working environment" (p.163). Park (2007) defined managerial coaching skills as a set of managerial coaching skills used to grasp everyday opportunities to improve their performance and maximize their potential. In the current study, we applied the conceptualization proposed by Park (2007) to define managerial coaching skills.

Open communication. Coaches must have well-developed communication skills and be able to speak clearly in one-on-one or group situations; they must also be able to convince people (Hudson, 1999). Evered and Selman 
(1989) indicated that a manager with effective coaching skills could achieve work results through quality communication with subordinates. The deepest interpersonal communication in coaching is based on trust, and requires open and non-threatening exchange (Quick, 2004).

Team approach. McLean et al. (2005) defined "team approach" managers as coaches who take a team approach rather than an individual approach. McLean and Tolbert defined this dimension as "preference for working with others when making decisions and achieving results" (Park, 2007, p.26). The team approach leads to motivated and productive employees (Chung \& Gfroerer, 2003).

Value people over task. A good coach must acknowledge an individual's needs and their application to tasks. The business world generally focuses on task-oriented rather than individual needs; this concept should be changed to people-oriented (Park, McLean, \& Yang, 2008). In addition, a manager acting as a coach "tends to value people over tasks, instead of other way around" (McLean et al., 2005, p.163).

Accept ambiguity. "Managers can accept ambiguity and need to open ideas to explore multiple solutions when working with employees" (Park, 2007, p.27). Good coaching can reduce the discomfort of uncertainty and help employees confront various challenges (Park, 2007). Specifically, subordinates perceive less role ambiguity or uncertainty when their supervisors assist them with problem solving, initiate and provide social support and resources (O'Driscoll \& Beehr, 1994).

Facilitate other's development. Slater and Narver (1995) characterized "the facilitative leader as a coach, help into surface assumptions and understand patterns and relationship among people, organization and events" (p.15). Yukl (1994) indicated that coaching includes facilitating learning, ensuring subordinates know the concept of development, providing feedback, and encouraging the application of skills on the job.

Previous scholars explored the effects of coaching on personal learning, manager's self-efficacy, affective organizational commitment, job satisfaction, and performance (Ellinger, Watkins \& Bostrom, 1999; Baron \& Morin, 2009; Ellinger, Ellinger, \& Keller, 2003). Park (2007) conducted a study on 187 employees and found a positive relationship between managerial coaching skills, personal learning, and organizational commitment. Yukl (1994) also suggested that empirical research on the effects of managerial coaching is required. However, evidence is relatively scant regarding the effect of a manager as coach on employee career development. Thus, the current study presents a discussion on occupational commitment.

\subsection{Occupational Commitment}

Recent research on commitment indicates that commitment can appear in different forms (Jaros, Jermier, Koehler, \& Sincich, 1993; Meyer \& Allen, 1991) and be directed toward various targets or foci (Becker \& Gerhart, 1996). Previous studies define occupational commitment as the "psychological link between an individual and his/her occupation that is based on an affective reaction to that occupation" (Lee et al., 2000, p.800). occupational commitment is a form of work commitment that individuals have on a career facet (Morrow, 1993). In addition, Marshall and Wijting (1982) defined occupational commitment as focus on one's general commitment to work throughout all stages.

Both Aranya et al. (1981) and Baugh and Roberts (1994) indicated that high occupational commitment leads to high job performance and job satisfaction. Baugh and Roberts (1994) found that engineers with higher occupational commitment were more likely to stay in their current profession and contribute more to their work.

In this study, we were particularly interested in this construct for two reasons. First, we expected that occupational commitment can facilitate employee effectiveness in an organization. When an employee incorporates his or her job into personal occupational development instead of considering it a mere duty to perform, he or she is more likely to exploit talents thoroughly in a particular area. Second, we expected that, with effective coaching skills, the occupational commitment of employees can be greatly enhanced. For example, Carson and Bedelian (1994) suggested that establishing the effects of supervisor support on occupational commitment is particularly crucial because doing so a key feature of self-managed careers. Yukl (1989) proposed that a leader should execute position responsibilities and delegate authority to influence follower's commitment.

\subsection{Perceived Organizational Support}

On the basis of organizational support theory (Eisenberger et al., 1986), Rhoades and Eisenberger (2002) said that three general froms of perceived favorable treatment received from the organization should increase POS. Treatment are such as fairness, supervisor support, and organizational rewards and job conditions. Perceived organizational support theory assumes that employees perceive general information on the amount that the organization cares for their well-being and values their contribution (Eisenberger, Cummings, Armeli, \& Lynch, 1997). Eisenberger, Stephen, Rexwinkel, Lynch, and Rhoades (2001) defined perceived organization support 
(POS) as an "experienced-based attribution concerning the benevolent or malevolent intent of the organization's policies, norm, procedures and actions as they affect employees" (p.42). Tansky and Cohen (2001) found a significant relationship between employee perception of organizational support and satisfaction of career development in their empirical study. More recently, Chen, Aryee, and Lee (2005) tested a mediation model of perceived organizational support using a Chinese sample, and reported that perceived organizational support is associated with positive work outcomes. Thus, this study investigates the connection between perceived organizational support and employee occupational commitment.

\subsection{Identity Theory}

The concept of "identity theory" provides a theoretical basis for understanding the structure of this study (Burke $\&$ Tully, 1977). Identity theory refers to the match between the individual meanings of a particular social role that enacts in that role when interacting with others (Burke \& Tully, 1977). Burke (1980, p.18) indicated that role identity includes the following: (1) identities are meanings that a person attributes to the self as an object in social situation or social role, (2) identities are relational, (3) identities are reflexive, and (4) identities are a source of motivation. In addition, roles do not stand in isolation; role identity is a social product, and (5) identities operate indirectly.

People received the message such as information, support or tasks, and they refer to the meaning of identity standard (Freese \& Burke, 1994). People then complete a process of repeated self-verification, meaning that they act to bring perceived self-relevant meanings in a situation that is based on feedback from others, and in part, on their perception of the environment. Someone's choice can cause different identities. In other words, the salience of identity is also a function of commitment to a role (Stryker \& Serpe, 1994). Greater commitment implies a greater correspondence between reflected appraisals of the external environment, and is consistent with an identity (Burke, 1999). Once people experience greater commitment to an identity and increase the strength of that identity, the more effort they put into enacting that role (Stryker, 1980). Because managerial coaching skills and organizational support constitute a source of external input for individual development, it would be useful to explore and understand how external social structures influence one's identity and occupational commitment.

\subsection{Hypothesis}

In the manager-subordinate relationship, effective managers can have genuine concern for employee interests and development needs. Managers should also act as a coach to facilitate employee career development by providing feedback on individual performance and information on future opportunities in the organization (Yarnall, 1998). Acting as a coach, managers can provide opportunities for career development and management development, instead of simply performance improvement (Evered \& Selman, 1989). Mayfield and Mayfield (2002) indicated that communication is a powerful bridge to translate behavioral intent to employees. A good leader can establish communication between workers and leaders, maintaining trust and an emotional connection with highly committed workers. A fundamental concept of building commitment process is to place people first; thus, it is important to treat employees as valued and respected individuals to increase employee commitment (Dessler, 1999). Therefore, this study hypothesizes the following:

Hypothesis 1: Managerial coaching skills are positively related to occupational commitment.

Blau (2003) studies a four-dimensional structure of occupational commitment which was based on Meyer et al.'s (1993) three dimension of commitment to occupations, named affective, normative and continuance occupational commitment. Meyer et al. (1993, p.540) explained "employees with stronger affective occupational commitment remain in their occupation because they want to, stronger normative occupational commitment because they feel they ought to, continuance commitment because they feel they feel need to." However, Blau (2001, p. 285) argued that "continuance occupational commitment should develop as the individual made investment (e.g. Employee status, time and effort acquiring occupation-specific skills) that would be lost or reduced if one changed occupations." Therefore, Blau (2001) suggested examining continuance occupational commitment as two separated dimensions: accumulated costs and limited alternatives occupational commitments. These two dimensions were based on Carson, Carson, \& Bedeian's (1995) concepts of occupational entrenchment: investment and emotional cost. Blau (2003) combined two dimension of "investment" and "emotional cost" and renamed to "accumulated costs occupational commitment"; after examining three kind of samples (medical technologists, working adults and executive MBAs), every sample reached the reliability of .85 to .90 . To brief previous definition of occupational commitment, this research adapted the definition of occupational commitment (Blau, 2001, 2003):

(1) affective occupational commitment (a person's emotional attachment to their occupation), (2) normative commitment ( a person's sense of obligation to remain in their occupation), (3) accumulated costs 
occupational commitment (accumulated investment such as time, money and emotional cost with pursuing new occupation), and (4) limited alternatives occupational commitment (perceived lack of available options for pursuing new occupation).

Previous research on the positive relationship between supervisor support and organizational support indicates that supervisor support leads to organizational support (Hutchison, 1997; Yoon, 2000). Hall and Marvis (as cited in Tansky \& Cohen, 2001) indicated that companies need a better understanding of how to provide work environments that not only support employee development, but also provide an atmosphere that encourages managers to care about their people. Baugh and Roberts (1994) suggested that once an organization supports the professional growth of its employees, it will increase its employees' organizational and professional commitment. Thus, the organization should strive to enhance employee career development.

Once an organization supports employee development, leaders generally perceive an improvement in employee retention, skills, and morale (Gutteridge, Leibowitz, \& Shore, 1993). Regarding identity theory, Foote (1951) and Gecas (1982) stated that identities are a source of motivation for actions, particularly when an identity interacts effectively with a social environment. Research shows that positive organizational and supervisor support has a positive effect on job satisfaction and commitment (Stassen, 2004). Burke (1999) claimed that a person's identity is verified in interaction with others. When the self-verification process is effectively developed, people are more committed and emotionally attached to the identity. A supportive organizational climate is required to achieve effective coaching in an organization. Such an environment encourages people to learn from their mistakes rather than blame them (Redshaw, 2000). Organizations should provide a safe and supportive environment to help their managers develop coaching skills (Ellinger \& Bostrom, 1999). In addition, to improve their techniques, employees expect the organization to partner with them (Fillery \& Lane, 2006). Employee development occurs when the organization sends a message to employees that the organization cares for their well-being and values their contribution (Nadler \& Nadler, 1989).

Young, Valach, and Collin (2002) suggested that emotions are an important factor in one's occupation, and are critical to creating a perspective within the psychology of working. Furthermore, managers with coaching skills can develop trust-based relationships with employees (Chung \& Gfroerer, 2003). However, according to identity theory, Burke (1999) viewed trust as a vital mechanism for improving commitment through self-verification. Kollock (1994) suggested that a trusting relationship must develop before any commitment can be created.

Workers who continue to invest resources in their jobs should experience increased job commitment (Rusbult \& Farrell, 1983). Career change is likely to involve difficult disruptions in self-identity and interpersonal relationships. When employees steadily invest in a job, they are less likely to divert their energies to searching for external opportunities (Brockner, 1992). Furthermore, once commitment exists, employees may cease to search for alternatives (Leik \& Leik, 1977).

To retain knowledge workers, managers must attract and motivate the best people by rewarding, training, and improving them (Webber, 1993). In addition, career identity is associated with work involvement, including professional orientation and commitment to managerial work (London, 1983). A manager with coaching skills can expose the learner to new and real working experiences by encouraging the learner to solve problems. This practice creates proactive learners with increased confidence in their positions (Redshaw, 2000). Based on the literature review, this study proposes the following hypotheses:

Hypothesis 2a: The relationship between managerial coaching skills and affective occupational commitment is mediated by perceived organizational support.

Hypothesis 2b: The relationship between managerial coaching skills and normative occupational commitment is mediated by perceived organizational support.

Hypothesis 2c: The relationship between managerial coaching skills and accumulated costs occupational commitment is mediated by perceived organizational support.

Hypothesis 2d: The relationship between managerial coaching skills and limited alternatives occupational commitment is mediated by perceived organizational support.

\section{Method}

\subsection{Participants and Procedure}

Convenient sample of on line and paper pencil survey were set up. Questionnaires were given out to those the authors of this study know of, and, mainly, the major source of data collections was classes of Executive MBA working adults nation-wide. The criterion was that the respondent served in a company and had a direct 
supervisor. A two-month data collection process generated 209 responses. The measurements in this study focus on employee perception of managers, themselves, and the organization. Because the sampling were Taiwanese, thus, Chinese language was the target language. The method of back-translation was used to prepare original questionnaires of managerial coaching skills, perceived organizational support, and occupational commitment. In the process of back-translation, two independent translators were involved. Translator one translated the English version of questionnaire into Chinese, then the second translator translated it back into English. The researchers of this study consulted with the translators to determine discrepancies.

\subsection{Measures}

Managerial Coaching Skills The questionnaire of managerial coaching skills was developed by McLean, Yang, Kuo, Tolbert, and Larkin (2005), who reported that the 20 items of four factors (open communication, team approach, value people over task, accepts ambiguity) formed a suitable fit structure with GFI of .87, RMR of .075 , and RMSEA of .076 . The reported value of coefficient alpha was .84 for combined four factors. This study uses a revised version of the questionnaire prepared by Park (2007) with a reported coefficient alpha of .93. This questionnaire includes 20 items in the five dimensions (open communication, team approach, value people over task, accept ambiguity, facilitate other's development) and reveals that $\chi^{2}(160)=427.19(\mathrm{p}<.01)$, $\mathrm{CFI}=.96$, and $\mathrm{SRMR}=.063$, with factor loadings between .52 and .90 . Cronbach's alpha reliability is .93 (Park, 2007).

Answers to items were recorded on a Likert-type scale with 6 responses, ranging from "strongly disagree $=1$ " to "strongly agree $=6 . "$. The design of 6-point Likert scale instead of 5-point Likert scale was to avoid ambivalent answer of middle response. Randomized polarity was used (with some descriptive items appearing on the left and others on the right) to determine people's perception of right or left descriptions. Sample items included the following: (1) open communication (for example, When I share my feelings with my manager, my manager appears to be comfortable or uncomfortable); (2) team approach (for example, When a decision is to be made, my manager prefers to determine the outcome him/herself versus participate with others to determine the outcome); (3) value people over tasks (for example, when facing conflict between individual needs and tasks, my manager prioritizes on completing the work or meeting people's needs); (4) accept ambiguity (for example, My manager views differences of opinion as destructive or constructive); and (5) facilitate other's development (for example, To improve my performance, my manager tells me what to do or serves as a role model).

Occupational Commitment This study uses Blau's (2003) scales to measure occupational commitment. These scales include 24 items on a 5 -point Likert-type scale $(1=$ strongly disagree, $5=$ strongly agree $)$. Sample items include the following: "I am happy to have entered the (occupation)" (affective occupation commitment); "I believe that people who have been trained in (occupation) have a responsibility to stay in that profession" (normative occupational commitment); "It would be very costly for me, income-wise, to switch my profession (occupation)" (accumulated costs occupational commitment); and "With my background and experience, there are other attractive alternative available to me in other professions (occupations)"(Reversed question) (limited alternatives occupational commitment). Four items of limited alternatives occupational commitment were reversed items. The coefficient alpha reliability for each dimension of occupational commitment is $.84, .85, .87$, and .86 , respectively.

Perceived Organizational Support Previous studies provide numerous occupations to prove the high internal reliability and unidimensionality of the survey of perceived organizational support (Eisenberger \& Huntington, 1986; Eisenberger, Fasolo, \& Davis, 1990; Shore \& Wayne, 1993). This study uses eight items of short version questionnaire by Park (2007) on a 7-point Likert-type scale $(1=$ strongly disagree, $7=$ strongly agree $)$, based on Eisenberger et al. (1997), with a coefficient alpha reliability of .90. Example items include the following: "Help is available from my organization when I have a problem" and "My organization cares about my opinions."

\section{Results}

\subsection{Data Analysis}

Table 1 shows the reliability statistics for the constructs measured in this study, indicating that every dimension falls into a standard range. Table 1 also reveals the correlations among various scales, including mean and stander deviation. For instance, between managerial coaching skills, affective occupational commitment, and normative occupational commitment are positively significantly related. A similar pattern of significant magnitude of similarity appears for perceived organizational support, affective occupational commitment, and normative occupational commitment. In addition, limited alternatives occupational commitment has a positive significant relationship with perceived organizational support. Also, , there is no significant relationship between managerial coaching skills, accumulated costs occupational commitment, and limited alternatives occupational 
commitment. It is noted that a limited amount of subscales reported slightly higher correlation (.70), however, most of the variables were within expected ranges. Therefore, the possibility of multicollinerity impact on the results of this study can be considered as minimal.

\subsection{Checking for Mono-method Bias}

Since the data of this research were collected from a single source, this study conducts Harman's single-factor test. Podsakoff, MacKenzie, Lee, \& Podsakoff (2003) reported that Harmon's single-factor test is one of the most widely used technique to address the issue of common Method variance (CMV). This test was conducted by entering all 52 items into the principle component analysis and testing the unrotated factor solution. The results of the Bartlett test of sphericity were significant $\left(\chi^{2}=6343.068, p<.000\right)$, showing that our sampling data were suitable for factor analysis. The 12 factors with an eigenvalue of more than 1.0 accounted for $68.589 \%$ of the variance. The first factor accounted for $23.338 \%$ of the variance. This means the items did not merge into one factor. According to two previous methods, this study could be distinguished into three factors, and the mono-method bias was not a serious problem. In addition, Zientek and Thompson (2009) suggested that researchers report a full covariance matrix or correlation matrix with means and standard deviations to allow for secondary analyses. Therefore, we provided the correlation matrix of examined variable data in Table 1 for further reference.

Table 1. Results of Harmon single-factor analysis

\begin{tabular}{llll}
\hline \multirow{2}{*}{ Factor } & \multicolumn{3}{l}{ Principle component analysis (no rotation) } \\
\cline { 2 - 4 } 1 & Eigenvalue Value & Variance $\%$ & Accumulated variance $\%$ \\
\cline { 2 - 4 } 2 & 12.136 & 23.338 & 23.338 \\
3 & 5.649 & 10.863 & 34.201 \\
4 & 3.967 & 7.628 & 41.829 \\
5 & 2.613 & 5.026 & 46.854 \\
6 & 2.429 & 4.672 & 51.526 \\
7 & 1.722 & 3.311 & 54.837 \\
8 & 1.479 & 2.844 & 57.681 \\
9 & 1.250 & 2.404 & 60.084 \\
10 & 1.234 & 2.372 & 62.457 \\
11 & 1.107 & 2.129 & 64.586 \\
12 & 1.067 & 2.051 & 66.637 \\
\hline
\end{tabular}

$N=209$

\subsection{Hypothesis Test}

Hypothesis 1 suggests that managerial coaching skills is positively related to occupational commitment. As shown in Table 2, managerial coaching skills are significantly related to occupational commitment $r=.26$ ( $p$ $<.01$ ), supporting Hypothesis 1. To test the mediated effect of Hypothesis 2, Baron and Kenny (1986) argued that mediation procedures must meet three conditions. First, the predictor (managerial coaching skills) must be related to the mediator (perceived organizational support). After controlling the control variables, managerial coaching skills are positively related with perceived organizational support $(B=.41, p<.001)$, satisfying Condition 1 (Table 2, model 2).

Table 2. Means, standard deviations, reliability, and intercorrelations 


\begin{tabular}{|c|c|c|c|c|c|c|c|c|c|c|c|c|}
\hline Variables & $\begin{array}{c}\text { Mea } \\
\mathbf{n}\end{array}$ & SD & 1 & 2 & 3 & 4 & 5 & 6 & 7 & 8 & 9 & 10 \\
\hline 1.Gender & 0.41 & 0.49 & & & & & & & & & & \\
\hline $\begin{array}{l}\text { 2.Occupational } \\
\text { tenure }\end{array}$ & 0.56 & 0.50 & 0.11 & & & & & & & & & \\
\hline 3.Education & 0.49 & 0.50 & $-0.23^{* *}$ & 0.05 & & & & & & & & \\
\hline $\begin{array}{l}\text { 4.Managerial } \\
\text { coaching skills }\end{array}$ & 3.35 & 0.82 & -0.07 & $-0.17^{*}$ & 0.08 & $(0.91)$ & & & & & & \\
\hline $\begin{array}{l}\text { 5.Affective } \\
\text { occupational } \\
\text { commitment }\end{array}$ & 3.71 & 0.70 & -0.07 & 0.08 & 0.05 & $0.27^{* *}$ & $(0.93)$ & & & & & \\
\hline $\begin{array}{l}\text { 6.Normative } \\
\text { occupational } \\
\text { commitment }\end{array}$ & 3.20 & 0.78 & -0.06 & 0.03 & -0.07 & $0.28^{* *}$ & $0.66^{* *}$ & (0.89) & & & & \\
\hline $\begin{array}{l}\text { 7.Accumulated } \\
\text { costs } \\
\text { occupational } \\
\text { commitment }\end{array}$ & 3.09 & 0.66 & $-0.19^{* *}$ & 0.04 & 0.07 & 0.08 & $0.31^{* *}$ & $0.41^{* *}$ & $(0.84)$ & & & \\
\hline $\begin{array}{l}\text { 8.Limited } \\
\text { alternatives } \\
\text { occupational } \\
\text { commitment }\end{array}$ & 2.46 & 0.68 & $0.14^{*}$ & -0.02 & $-0.17^{*}$ & 0.02 & -0.11 & -0.03 & $0.16^{*}$ & $(0.82)$ & & \\
\hline $\begin{array}{l}\text { 9.Occupational } \\
\text { commitment }\end{array}$ & 3.12 & 0.46 & -0.06 & 0.05 & -0.04 & $0.26^{* *}$ & $0.73^{* *}$ & $0.80^{* *}$ & $0.70^{* *}$ & $0.37^{* *}$ & $(0.89)$ & \\
\hline $\begin{array}{l}\text { 10.Perceived } \\
\text { organizational } \\
\text { support }\end{array}$ & 4.40 & 1.10 & 0.04 & -0.05 & 0.02 & $0.42^{* *}$ & $0.49^{* *}$ & $0.56^{* *}$ & 0.11 & $-0.17^{*}$ & $0.40^{* *}$ & $(0.89)$ \\
\hline
\end{tabular}

Note. $\mathrm{N}=209 * * \mathrm{p}<0.01, * \mathrm{p}<0.05$ (two-tailed)

Second, the predictor (managerial coaching skills) must be related to dependent variables (affective occupational commitment, normative occupational commitment, accumulated costs occupational commitment and limited alternatives occupational commitment). Only affective occupational commitment $(B=.27, p<.001)$ and normative occupational commitment $(\beta=.28, \mathrm{p}<.001)$ met Condition 2. People who perceived more managerial coaching skills also felt more affective and normative occupational commitment (Table 2, Models 4 and 7).

Third, when both the predictor (managerial coaching skills) and the mediator (perceived organizational support) are simultaneously added to the regression equation, the relationship between predictor and criterion must become weaker (partial mediation) or non-significant (full mediation), but the relationship between mediator and criterion must remain significant. According to Condition 2, only affective and normative occupational commitment were supported. As for Condition 3, results (Table 2, Model 5 and Model 8) show that the regression equations of mediator (perceived organizational support) and affective occupational commitment ( $(\beta=$ $42, \mathrm{p}<.001)$ and normative occupational commitment $(B=.52, \mathrm{p}<.001)$ were significant. Furthermore, managerial coaching skills did not significantly predict affective occupational commitment $(\beta=.10, p>.05)$ or normative occupational commitment $(\beta=.07, \mathrm{p}>.05)$. Hence, Condition 3 was satisfied, confirming the full mediation of the relationship between managerial coaching skills and affective occupational commitment (Hypothesis 2a), as well as full mediation of the relationship between managerial coaching skills and normative occupational commitment (Hypothesis 2b). We then assessed mediation by using the Sobel test, which is a traditional method for testing the significance of mediation effects. The z-value provided by the Sobel test, which was used to evaluate the mediated effect of Hypothesis 1 , was 5.458, $p<.000$, and the z-value provided by the Sobel test, which was used to evaluate the mediated effect of Hypothesis 2 , was 5.168, $p<.000$. This also shows full mediation in both cases. There were no mediation effects for the relationship between managerial coaching skills, accumulated costs occupational commitment, and limited alternatives occupational commitment 
(Hypotheses 2c and 2d).

The hierarchical regression in Table 2 indicates that the dependent variable of affective occupational commitment $(\beta=.34, \mathrm{p}<.001$, Model 3$)$ and normative occupational commitment $(\beta=.27, \mathrm{p}<.001$, Model 6$)$ were related to the control variable of non-manager (Code 0) and manager (Code 1). Compared to the non-manager group, the manager group scored higher on affective and normative occupational commitment. Although Hypotheses $2 \mathrm{c} \& 2 \mathrm{~d}$ were not supported, there is a significant relationship between gender (male code 0 , female code 1) and accumulated costs occupational commitment. Table 2 (Model 9) shows that the statistic of gender and accumulated costs occupational commitment was $B=-.17, p<.05$. These results indicate that, compared with the male group, the female group had less accumulated costs occupational commitment. Table 2 (Model 12) also indicates a significant difference between age, education, and limited alternatives occupational commitment. The result of age (below 35-year-old code 0 , above 35 -year-old code 1 ) was $\beta=.23, p<.01$. This indicates that the limited alternatives occupational commitment for those 35 years or older was higher than for those younger than 35. Regarding education, employees with undergraduate degrees (senior high, college) compared to post-graduates (Master or Ph.D. degrees) had more limited alternatives occupational commitment ( $B$ $=-.19, \mathrm{p}<.05)$. In other words, people with advanced degrees perceived more external opportunities, which consequently led to lower limited occupational commitment.

Table 3. Intercorrelations between control variables and examined variables

\begin{tabular}{|c|c|c|c|c|c|c|c|c|c|c|c|c|c|c|c|}
\hline Variables & 1 & 2 & 3 & 4 & 5 & 6 & 7 & 8 & 9 & 10 & 11 & 12 & 13 & 14 & 15 \\
\hline 1.Gender & 1.00 & & & & & & & & & & & & & & \\
\hline 2.Age & -.08 & 1.00 & & & & & & & & & & & & & \\
\hline 3.OT & .08 & $.52 *$ & 1.00 & & & & & & & & & & & & \\
\hline 4.CWT & .09 & $.25^{*}$ & $.54^{*}$ & 1.00 & & & & & & & & & & & \\
\hline 5. EDU & $-.25^{*}$ & .01 & .03 & -.00 & 1.00 & & & & & & & & & & \\
\hline 6. IND & .09 & -.06 & -.05 & -.10 & $-.20 *$ & 1.00 & & & & & & & & & \\
\hline 7. SIZE & -.11 & -.03 & .08 & -.00 & $.58^{*}$ & $-.26^{*}$ & 1.00 & & & & & & & & \\
\hline 8. MANAGE & -.04 & $.40 *$ & $.31 *$ & .14 & -.07 & .09 & -.04 & 1.00 & & & & & & & \\
\hline 9.MCS & -.07 & -.08 & -.09 & -.04 & .08 & -.03 & -.04 & .05 & 1.00 & & & & & & \\
\hline 10.AOC & -.06 & $.16^{*}$ & .13 & .05 & .01 & -.04 & .06 & $.32 *$ & $.26^{*}$ & 1.00 & & & & & \\
\hline 11. NOC & -.06 & .05 & .05 & .03 & -.05 & -.06 & -.01 & $.23 *$ & $.28 *$ & $.66^{*}$ & 1.00 & & & & \\
\hline 12. ACO & $-.17 *$ & .06 & .06 & .04 & .09 & .06 & .10 & .12 & .08 & $.31 *$ & $.41^{*}$ & 1.00 & & & \\
\hline 13.LAO & $.15^{*}$ & $.16^{*}$ &.-.06 & -.06 & -.12 & .04 & -.06 & -.02 & .02 & -.11 & -.03 & $.16^{*}$ & 1.00 & & \\
\hline $14 . \mathrm{OC}$ & -.06 & $.17 *$ & .09 & .03 & -.01 & -.01 & .01 & $.24 *$ & $.26^{*}$ & $.73 *$ & $.80^{*}$ & $.70 *$ & $.80^{*}$ & 1.00 & \\
\hline 15.POS & .03 & .02 & .04 & .01 & .01 & .01 & -.06 & $.21^{*}$ & .42 & .49 & .56 & .11 & $-.17 *$ & $.40 *$ & 1.00 \\
\hline
\end{tabular}

Note. $\mathrm{N}=209 * p<0.05$ (two-tailed); 1=Gender; 2=Age; 3=Occupational tenure; 4=Co-working tenure with management; 5=education;6=Industry; 7=Firm size; 8=Management position; 9=Managerial coaching skills; 10=Affective occupational commitment; $11=$ Normative occupational commitment; $12=$ Accumulated occupational commitment; $13=$ limited alternative occupational commitment; 14= Occupational commitment; $15=$ Perceived organizational support

\section{Discussion}

Though previous research details the influence of supervisor support for subordinate's career development, further research on the effectiveness of specific management skill is necessary. Thus, this study examines the relationship between managerial coaching skills and occupational commitment as mediated by perceived 
organizational support. The results of this study bridge the gap between coaching literature and perceived organizational support as well as occupational commitment. We also provided additional information on how to enhance the occupational commitment of employees through coaching skills to achieve perceived organizational support. Results confirm Hypothesis 1, which predicts a positive relationship between managerial coaching skills and occupational commitment.

Table 4. Hierarchical regression results

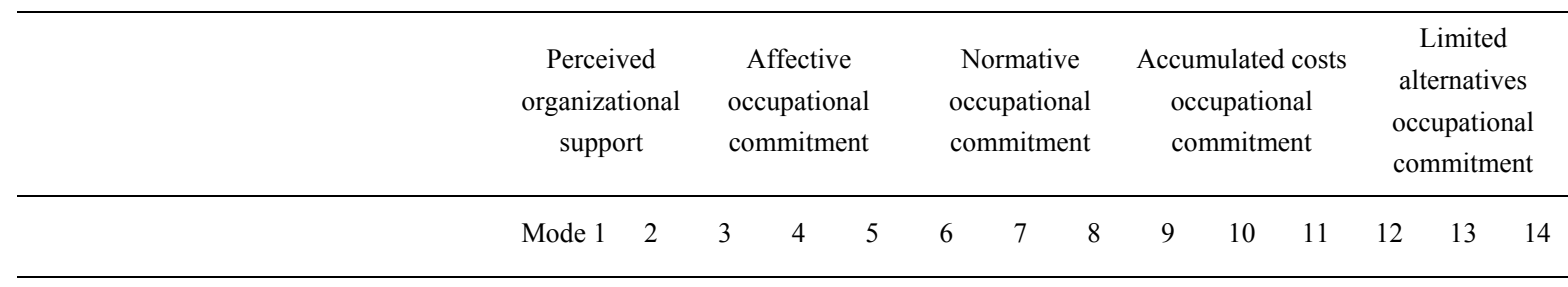

\section{Control variables}

\begin{tabular}{|c|c|c|c|c|c|c|c|c|c|c|c|c|c|c|}
\hline Gender $(0=$ male, $1=$ female $)$ & 0.07 & 0.08 & -0.04 & -0.03 & -0.06 & -0.07 & -0.06 & -0.10 & $\begin{array}{c}-0.17 \\
*\end{array}$ & $\begin{array}{c}-0.17 \\
*\end{array}$ & $\begin{array}{c}-0.17 \\
*\end{array}$ & 0.13 & 0.13 & 0.15 \\
\hline Age $(0=$ below $35,1=$ above 35$)$ & -0.10 & -0.07 & -0.07 & -0.05 & -0.02 & -0.12 & -0.11 & -0.07 & -0.02 & -0.02 & -0.01 & $\begin{array}{c}0.23 \\
* *\end{array}$ & $\begin{array}{c}0.23 \\
* *\end{array}$ & $\begin{array}{c}0.21 \\
* *\end{array}$ \\
\hline $\begin{array}{l}\text { Occupational Tenure }(0=\text { below } 3 \text { years, } 1 \\
=\text { above } 3 \text { years })\end{array}$ & -0.14 & -0.05 & 0.02 & 0.08 & 0.10 & 0.00 & 0.06 & 0.08 & 0.02 & 0.04 & 0.04 & -0.01 & 0.00 & -0.01 \\
\hline $\begin{array}{l}\text { Co-working tenure with mgr. }(0=\text { below } 3 \text {, } \\
1=\text { above } 3)\end{array}$ & 0.09 & 0.06 & -0.01 & -0.03 & -0.06 & 0.02 & 0.00 & -0.03 & 0.04 & 0.03 & 0.02 & -0.11 & -0.11 & -0.10 \\
\hline $\begin{array}{l}\text { Education }(0=\text { undergraduate, } 1=\text { post } \\
\text { graduate })\end{array}$ & 0.08 & 0.03 & 0.07 & 0.03 & 0.02 & -0.05 & -0.09 & -0.10 & -0.03 & -0.04 & -0.04 & $\begin{array}{c}-0.19 \\
*\end{array}$ & $\begin{array}{c}-0.19 \\
*\end{array}$ & $\begin{array}{c}-0.19 \\
*\end{array}$ \\
\hline $\begin{array}{l}\text { Industry }(0=\text { technology, } 1= \\
\text { non-technology })\end{array}$ & -0.02 & -0.05 & 0.02 & 0.00 & 0.02 & 0.01 & -0.01 & 0.02 & 0.11 & 0.10 & 0.11 & 0.03 & 0.03 & 0.02 \\
\hline $\begin{array}{l}\text { irm size }(0=\text { below } 300 \text { employee , } 1= \\
\text { above } 300)\end{array}$ & 0.00 & 0.05 & 0.00 & 0.03 & 0.01 & -0.01 & 0.02 & -0.01 & 0.04 & 0.05 & 0.05 & 0.04 & 0.04 & 0.06 \\
\hline Management $(0=$ non-mgr. $1=$ mgr. $)$ & $0.27 * *$ & $\begin{array}{c}0.22 \\
* *\end{array}$ & $\begin{array}{l}0.34 \\
* * *\end{array}$ & $\begin{array}{l}0.31 \\
* * *\end{array}$ & $\begin{array}{c}0.21 \\
* *\end{array}$ & $\begin{array}{l}0.27 \\
* * *\end{array}$ & $\begin{array}{l}0.24 \\
* * *\end{array}$ & 0.12 & 0.13 & 0.12 & 0.10 & -0.08 & -0.09 & -0.04 \\
\hline Independent variable & & & & & & & & & & & & & & \\
\hline Managerial coaching skills & & $\begin{array}{l}0.41 \\
* * *\end{array}$ & & $\begin{array}{l}0.27 \\
* * *\end{array}$ & 0.10 & & $\begin{array}{l}0.28 \\
* * *\end{array}$ & 0.07 & & 0.07 & 0.03 & & 0.06 & 0.15 \\
\hline Mediator & & & & & & & & & & & & & & \\
\hline Perceived organizational support & & & & & $\begin{array}{l}0.42 \\
* * *\end{array}$ & & & $\begin{array}{l}0.52 \\
* * *\end{array}$ & & & 0.09 & & & $\begin{array}{l}-0.22 \\
* *\end{array}$ \\
\hline $\mathrm{R}^{2}$ & 0.08 & 0.23 & 0.11 & 0.17 & 0.31 & 0.07 & 0.15 & 0.35 & 0.07 & 0.07 & 0.08 & 0.09 & 0.09 & 0.13 \\
\hline$\triangle \mathrm{R}^{2}$ & 0.08 & 0.15 & 0.11 & 0.07 & 0.13 & 0.07 & 0.07 & 0.20 & 0.07 & 0.00 & 0.01 & 0.09 & 0.00 & 0.04 \\
\hline $\mathrm{F}$ & $2.03 *$ & $\begin{array}{c}39.91 \\
* * *\end{array}$ & $\begin{array}{l}2.98 \\
* *\end{array}$ & $\begin{array}{c}16.33 \\
* * *\end{array}$ & $\begin{array}{l}38.52 \\
* * *\end{array}$ & $2.00 *$ & $\begin{array}{c}16.71 \\
* * *\end{array}$ & $\begin{array}{l}62.48 \\
* * *\end{array}$ & 1.74 & 0.88 & 1.33 & 2.47 & 0.72 & $8.37^{*}$ \\
\hline
\end{tabular}

Note. $\mathrm{N}=209 ;{ }^{*} \mathrm{p}<0.05,{ }^{* *} \mathrm{p}<0.01,{ }^{* * *} \mathrm{p}<0.001$, indicates are standardized regression weights

Hypotheses $2 \mathrm{a}$ and $2 \mathrm{~b}$ were also positively supported, indicating that both affective and normative occupational commitment are mediated by perceived organizational support. Individuals are motivated to formulate plans and perform activities that reinforce, support, and confirm their identities. 
According to identity theory, Burke (1991) suggested several factors that maintain an individual's identity and also serve as bases of commitment. The first factor includes rewards and positive evaluations of the identities, which form the cognitive basis for commitment. Second, interacting with others with warmth forms the socio-basis for commitment. Craumer (2001) suggested that those who feel valued and respected by their employers tend to be more loyal and work harder because they receive more than a job. Blustein (2006) defined working as a way to establish an identity. Therefore, it contributes to personal meaning, and involves effort and activity. Work involved in physical, social and psychological needs, supervisor, and organization that meted these needs could help people successfully in choosing career. Meyer et al. (1993) revealed that normative pressures occur when people receive a benefit that creates a sense of obligation. Employees' perceptions of a supportive climate in the organization affect the manner in which they view their jobs (Wilson, Dejoy, Vandenberg, Richardson, \& McGrath, 2004). Therefore, the combination of managerial coaching skills (open communication, team approach, value people over task, accept ambiguity, facilitate others' development) and organizational support can improve employee affective and normative occupational commitment. Thus, the results of this study support Hypotheses $2 \mathrm{a}$ and $2 \mathrm{~b}$.

Through the stimuli of organizational support, managerial coaching skills influence employee affective and normative occupational commitment, but have no effect on accumulated costs and limited alternatives occupational commitment. Hall (1995 \& 1996) suggested that proactive career development is related to personal responsibility and self-awareness of development. Continuing learning becomes a key part of employee's continuing career success. This may be because accumulated costs and external alternatives on career are more related to personal attitudes on the career that cannot be influenced by external inputs, such as manager coaching skills or organizational support.

Though Hypotheses $2 \mathrm{c}$ and $2 \mathrm{~d}$ were not supported, there is a significant relationship between gender and accumulated costs of occupational commitment; females exhibited less accumulated costs occupational commitment than males. This may be due to the significant role women play in a family; women may begin family life or choose parenting alternatives during their career development (White, 1995). In addition, age and education have a significant relationship with limited alternatives occupational commitment. Those aged 35 or older exhibited more limited alternatives occupational commitment. This may be because once people become devoted to an occupational field, they become domain experts who must continue to work in this occupation. Ackerman (1996), Ackerman and Rolfthus (1999), and Beier and Ackerman (2001) showed that age-related increases in crystallized intellectual abilities (that is, domain knowledge, expertise in special field) may compensate for a decline in fluid intellectual abilities (that is, working memory, attention, and processing of novel information) in jobs that optimize existing knowledge and skills. Lastly, education of below undergraduate level perceived more limited alternatives occupational commitment, perhaps the increase of undergraduate students in Taiwan cause them felt more external pressure for seeking alternatives.

\subsection{Managerial Implications}

This study has two implications for management. First, based on the mediating effect of perceived organizational support on managerial coaching skills, affective and normative occupational commitment, managerial coaching skills and organizational support could be the resource of emotional and normative committed to occupation. In other words, the influence of managerial coaching affects the occupational commitment of employees by the enhancing perceived organizational support. Thus, it is important to persuade managers to practice coaching skills with employees in that it could indirectly help employees become more emotionally attached to their occupations.

Second, unpredictable working environments reveal a shift from organizational careers to careers that are based on self-direction and a pursuit of psychological success in personal career development (Hall, 1976). However, employee development is not only the manager's duty; it also requires the organization to provide a supportive environment and value employee efforts. Once employees know the meaning of work and find their own identities, they can contribute more professional productivity to the organization. Since career development is one part of HRD to develop a well system of manager and organization support for a development culture becomes an important issue. Thus, a company that offers a better working environment could retain valuable people (May, Lau, \& Johnson, 1999).

\section{Conclusions}

The results of this study have both theoretical and practical implications. Theoretically, identity theory proposes that the match between the individual meanings of a particular social role that enacts in that role when interacting with others (Burke \& Tully, 1977) and identification of managers can be a source of motivation and 
commitment. Based on these assumptions, the results of this study offer an innovative perspective for examining commonly investigated constructs of perceived organizational support and occupational commitment and help to identify practical strategies for human resource practice. From a practical perspective, by facilitating the coaching skills of managers, employees can develop stronger occupational commitment and are more likely to perceive organizational support. To build on the present findings, future researchers should consider longitudinal designs to examine whether changes in coaching skills will predict changes in the perceived organizational support of employees and occupational commitment.

\subsection{Limitations of This Study}

Several limitations of this study should be noted in this study. First, the sample was restricted to employees in Taiwan and limits generalizability to other cultures. Second, the results were based on self-reported data, and therefore were subject to human error or memory recall bias. It is possible that social desirability might affect the way participants answer the items. To build on the present findings, interested researchers should consider using different data collection method as well as a diverse sample to examine the coaching skills in relation to different constructs. The comparison of different cultures on coaching skills may be a fruitful target for future study.

\section{References}

Ackerman, P. L. (1996). A theory of adult intellectual development: Process, personality, interests, and knowledge. Intelligence, 22, 229-259. http://dx.doi.org/10.1016/S0160-2896(96)90016-1

Ackerman, P. L., \& Rolfhus, E. L. (1999). The locus of adult intelligence: Knowledge, abilities, and non-ability traits. Psychology and Aging, 14, 314-330. http://dx.doi.org/10.1037/0882-7974.14.2.314

Baron, L., \& Morin, L. (2009). The impact of executive coaching on self-efficacy related to management soft-skills. Leadership \& Organization Development Journal, 13(1), 18-38.

Baron R. M., \& Kenny, D. A. (1986). The moderator-mediator variable distinction in social psychological research: Conceptual, strategic, and statistical considerations. Journal of Personality and Social Psychology, 51(6), 1173-1182. http://dx.doi.org/10.1037/0022-3514.51.6.1173

Baruch, Y. (2004). Transforming careers: From linear to multidirectional career paths. Career Development International, 9(1), 58-73. http://dx.doi.org/10.1108/13620430410518147

Baugh, S. G., \& Roberts, R. M, (1994). Professional and organizational commitment among engineer: Conflicting or complementing? IEEE Transactions on Engineering Management, 41(2), 108-114. http://dx.doi.org/10.1109/17.293377

Becker, B., \& Gerhart, B. (1996). The impact of human resource management on organizational performance: Progress and prospects. Academy of Management Journal, 39(4), 779-801. http://dx.doi.org/10.2307/256712

Beier, M. E., \& Ackman, P. L. (2001). Current events knowledge in adults: An investigation of age, gender, abilities, personality, and interests. Journal of Personality and Social Psychology, 84, 439-448. http://dx.doi.org/10.1037/0022-3514.84.2.439

Blau, G. (2001). Testing the discrimination validity of occupational entrenchment. Journal of Occupational Psychology, 58, 277-288. http://dx.doi.org/10.1111/j.2044-8325.1985.tb00201.x

Blau, G. (2003). Testing for a four-dimensional structure of occupational commitment. Journal of Occupational and Organizational Psychology, 76, 469-488. http://dx.doi.org/10.1348/096317903322591596

Blustein, D. L. (2006). The psychology of work: A new perspective for career development, consulting, and public policy. NJ: Lawrence Erlbaum Associates.

Brockner, J. (1992). The escalation of commitment to a failing course of action: Toward theoretical progress. Academy of Management Review, 17, 39-61.

Brown, S. D., \& Lent, R. D. (1996). A social cognitive framework for career choice counseling. The Career Development Quarterly, 44(4), 354-366. http://dx.doi.org/10.1002/j.2161-0045.1996.tb00451.x

Burke, P. J., \& Tully, J. C. (1977). The measurement of role identity. Social Forces, 55(4), 881-897.

Burke, P. J. (1980). The self: Measurement requirements from an interactions perspective. Social Psychology Quarterly, 43(1), 19-29. http://dx.doi.org/10.2307/3033745

Burke, P. J. (1991). Identity process and social stress. American Sociological Review, 56(6), 836-849. http://dx.doi.org/10.2307/2096259 
Burke, P. J. (1999). Trust and commitment through self-verification. Social Psychology Quarterly, 62(4), 347-360. http://dx.doi.org/10.2307/2695833

Carson, K. D., \& Bedelian, A. G. (1994). Career commitment: Construction of measurement and examination of it psychometric properties. Journal of Vocational Behavior, 44, 237-262. http://dx.doi.org/10.1006/jvbe.1994.1017

Carson, K. D., Carson, P. P., \& Bedeian, A. (1995). Development and construct validation of career entrenchment measure. Journal of Occupational and Organizational Psychology, 68, 301-320. http://dx.doi.org/10.1111/j.2044-8325.1995.tb00589.x

Chung, Y. B., \& Gfroerer, M. C. (2003). Career coaching: Practice, training, professional, and ethical issues. The Career Development Quarterly, 52(2), 141-152. http://dx.doi.org/10.1002/j.2161-0045.2003.tb00634.x

Chen, Z. X., Aryee, S., \& Lee, C. (2005). Test of a mediation model of perceived organizational support. Journal of Vocational Behavior, 66, 457-470. http://dx.doi.org/10.1016/j.jvb.2004.01.001

Colarelli, S. M., \& Bishop, R. C. (1990). Career commitment: Functions, correlates, and management. Group \& Organization Studies, 15(2), 158-176. http://dx.doi.org/10.1177/105960119001500203

Craumer, M. (2001). How to coach your employees: Focus on their strengths, not their weakness. Harvard Management Communication Letter, December, 9-11.

Dessler, D. (1999). How to earn your employees' commitment. The Academy of Management, 13(2), 58-67.

Eisenberger, R., Cummings, J., Aremeli, S., \& Lynch, P. (1997). Perceived organizational support, discretionary treatment, and job satisfaction. Journal of Applied Psychology, 82, 812-820. http://dx.doi.org/10.1037/0021-9010.82.5.812

Eisenberger, R., Fasolo, P., \& Davis, L. V. (1990). Perceived organizational support and employee diligence, commitment, and innovation. Journal of Applied Psychology, 75, 51-59. http://dx.doi.org/10.1037/0021-9010.75.1.51

Eisenberger, R., \& Huntington, R. (1986). Perceived Organizational Support. Journal of Applied Psychology, 71, 500-507. http://dx.doi.org/10.1037/0021-9010.71.3.500

Eisenberger, R., Stephen, A., Rexwinkel, B., Lynch, P. D., \& Rhoades, L. (2001). Reciprocation of perceived organizational support. Journal of Applied Psychology, 86(1), 42-51. http://dx.doi.org/10.1037/0021-9010.86.1.42

Ellinger, A. D., \& Bostrom, R. P. (1999). Managerial coaching in learning organizations. Journal of Management Development, 18(9), 752-771. http://dx.doi.org/10.1108/02621719910300810

Ellinger, A. D., Ellinger A. E., \& Keller, S. B. (2003). Supervisory coaching behavior, employee satisfaction, and warehouse employee performance: A dyadic perspective in the distribution industry. Human Resource Development Quarterly, 14, 435-458. http://dx.doi.org/10.1002/hrdq.1078

Ellinger, A. E., Ellinger, A. D., \& Keller, S. B. (2005). Supervisor coaching in a logistics context. International journal of physical distribution \& logistics management, 35(9), 620-636. http://dx.doi.org/10.1002/hrdq.1078

Ellinger, A. D., Watkins, K. E., \& Bostrom, R. P. (1997). Managers as facilitators of learning in learning organizations. Human Resource Development Quarterly, 10(2), 105-125. http://dx.doi.org/10.1002/hrdq.3920100203

Evered, R. D., \& Selman, J. C. (1989). Coaching and the art of management. Organization Dynamics, 18(2), 16-32. http://dx.doi.org/10.1016/0090-2616(89)90040-5

Fillery, A., \& Lane, D. (2006). Does coaching work or we asking the wrong question? International Coaching Psychology Review, 1(1), 23-36.

Foote, N. N. (1951). Identification as the Basis for a theory of motivation. American Sociological Review, 16(1), 14-21. http://dx.doi.org/10.2307/2087964

Freese, L., \& Burke, P. J. (1994). Persons, identities, and social interaction. In M. Barry, H. Karen, \& O. Jodi (Eds.), Advance in group process (pp. 1-24). Greenwitch, CT: JAI.

Geber, B. (1992). From manager into coach. Training, 29(2), 25-31.

Gecas, V. (1982). The self-concept. Annual Review of Sociology, 8, 1-33. 
http://dx.doi.org/10.1146/annurev.so.08.080182.000245

Gilley, J., Eggland, S., \& Gilley, A. (2002). Principles of Human Resource Development. New York: Basic Books.

Goleman, D. (2000). Leadership that get results. Harvard Business Review, 78(2), 78-90.

Graham, S., Wedman, J. F., \& Kester, B. G. (1994). Manager coaching skills: What makes a good coach? Performance Improvement Quarterly, 7(2), 81-94. http://dx.doi.org/10.1111/j.1937-8327.1994.tb00626.x

Gutteridge, T. G., Leibowitz, Z. B., \& Shore, J. E. (1993). When careers flows, organizations flourish. Training and development, November, 25-29.

Hagen, M. (2012). Managerial coaching: A review of the literature. Performance Improvement Quarterly, 24(4), 17-39. http://dx.doi.org/10.1002/piq.20123

Hall, D. T. (1976). Careers in organizations. Pacific Palisades, CA: Goodyear.

Hall, D. T. (1995). The new career contract: Developing the whole person at midlife and beyond. Journal of Vocational Behavior, 47, 269-289. http://dx.doi.org/10.1006/jvbe.1995.0004

Hall, D. T. (1996). Protean careers of the $21^{\text {st }}$ century. The Academy of Management Executives, 10(4), 8-16.

Hamlin, R. G., Ellinger, A. D., \& Beattie, R. S. (2009). Toward a process of coaching? A definitional examination of "Coaching," "Organization Development," and "Human Resource Development". International Journal of Evidence Based Coaching and Mentoring, 7, 12-38.

Hudson, F. D. (1999). The hand book of coaching: A comprehensive resource guide for managers, executives, consultants, and human resource professionals. San Francisco, CA: Jossey Bass.

Hutchison, S. (1997). A path model of perceived organizational support. Journal of Social Behavior and Personality, 12(1), 159-174.

Hunt, J. M., \& Weintraub, J. R. (2002). The coaching manager: Developing top talent in business. Thousand Oaks, CA: Sage.

Jaros, S. J., Jermier, J. M., Koehler, J. W., \& Sincich, T. (1993). Effects of continuance, affective, and moral commitment on the withdrawal process: An evaluation of eight structural equation models. Academy of Management Journal, 36, 951-995. http://dx.doi.org/10.2307/256642

Johnson, R. A. (1996). Antecedents and outcomes of corporate refocusing. Journal of Management, 22(3), 439-483. http://dx.doi.org/10.1177/014920639602200304

Kidd, J. M., \& Smewing, C. (2001). The role of the supervisor in career and organizational commitment. European Journal of Work and Organizational Psychology, 10(1), 25-40. http://dx.doi.org/10.1080/13594320042000016

Kram, K. E. (1983). Phase of the mentor relationship. Academy of Management Journal, $26(4), 608-625$. http://dx.doi.org/10.2307/255910

Kollock, P. (1994). The emergence of exchange structures: An experimental study of uncertainty, commitment, and trust. American Journal of Sociology, 100, 313-345. http://dx.doi.org/10.1086/230539

Kozlowski, S. W., \& Hults, B. M. (1987). An exploration of climates for technical updating and performance. Personnel psychology, 40, 539-563. http://dx.doi.org/10.1111/j.1744-6570.1987.tb00614.x

Lee, K., Carswell, J., \& Allen, N. (2000). A meta-analytic review of occupational commitment: Relationships with person and work-related variables. Journal of Applied Psychology, 85, $799-811$. http://dx.doi.org/10.1037/0021-9010.85.5.799

Leik, R. K., \& Leik, S. K. (1977). Transition to interpersonal commitment. In R. L. Hamblin, \& J. H. Kunkle (Eds.), Behavior Theory in Society (pp. 299-305). NJ: Transation Books.

London, M. (1983). Toward a theory of career motivation. The Academy of Management Review, 8(4), 620-630.

Marshall, S. J., \& Wijting, J. P. (1982). Dimension of women's career orientation. Sex Roles, 8(2), $135-146$. http://dx.doi.org/10.1007/BF00287918

May, B. E., Lau, R. S. M., \& Johnson, S. K. (1999). A longitudinal study of quality of work life and business performance. South Dakota Business Review, 58(2), 3-7.

Mayfield, J., \& Mayfield, M. (2002). Leader communication strategies critical path to improving employee 
commitment. American Business Review, June, 89-94.

Meyer, J. P., Allen, N., \& Smith, C. (1993). Commitment to organizations and occupations: Extension and test of three-components conceptualization. Journal of Applied Psychology, 78, 538-551. http://dx.doi.org/10.1007/BF00287918

McGill, M. E., \& Slocum, Jr., J. W. (1998). A little leadership please? Organizational Dynamics, 26(3), 39-49. http://dx.doi.org/10.1016/S0090-2616(98)90013-4

McLagan, P. (1989). Models for HRD practice. ASTD Press, St Paul, Minnesota.

McLean, G. N., \& Kuo, M. C. (2000). Coaching in organizations: Self-assessment of competence. In K. P. Kuchinke (Ed.), Proceedings of the Academy of Human resource Development Conference (pp. 638-645). Raleigh-Durham, NC: Academy of Human Resource Development.

McLean, G. N., Yang, B., Kuo, M. C., Tolbert, A. S., \& Larkin, C. (2005). Development and initial validation of an instrument measuring managerial coaching skill. Human Resource Development Quarterly, 16(2), 157-178. http://dx.doi.org/10.1002/hrdq.1131

Meyer, J. P., \& Allen, N. J. (1991). The three-component conceptualization of organizational commitment. Human Resource Management Review, 1(1), 61-89. http://dx.doi.org/10.1016/1053-4822(91)90011-Z

Meyer, J. P., Allen, N., \& Smith, C. (1993). Commitment to organizations and occupations: extension and test of three-components conceptualization. Journal of Applied Psychology, 78, 538-551. http://dx.doi.org/10.1037/0021-9010.78.4.538

Morrow, P. C. (1993). The theory and measurement of work commitment. Greenwitch, CT: JAI Press.

Nadler, L., \& Nadler, Z. (1989). Developing human resources (3rd ed.). San Francisco, CA: JosseY-Bass.

Noe, R. A., \& Ford, J. K. (1992). Emerging issues and new directions for training research. In G. R. Ferris, \& K. M. Rowland (Eds.), Research in personnel and human resources management (pp. 345-384). Greenwich, CT: JAI Press.

O'driscoll, M. P., \& Beehr, T. A. (1994). Supervisor behavior, role stressor and uncertainty as predictors of personal outcomes for subordinates. Journal of organizational behavior, 15, 141-155. http://dx.doi.org/10.1002/job.4030150204

Orth, C. D., Wilkinson, H. E., \& Benfari, R. C. (1987). The manager's role as coach and mentor. Organizational Dynamics, 15(4), 66-74. http://dx.doi.org/10.1016/0090-2616(87)90045-3

Park, S. (2007). Relationships among managerial coaching in organizations and the outcomes of personal learning, organizational commitment, and turnover intention (Unpublished doctoral dissertation). University of Minnesota, Minneapolis, Minnesota.

Park, S., McLean, G. N., \& Yang, B. (2008, February). Revision and validation of an instrument measuring managerial coaching skills in organizations. Academy of Human Resource Development International Research Conference. Conference conducted in Panama City.

Peterson, D. B., \& Little, B. (2005). Invited reaction: development and initial validation of an instrument measuring managerial coaching skill. Human Resource Development Quarterly, 16(2), 179-184. http://dx.doi.org/10.1002/hrdq.1132

Podsakoff, P. M., MacKenzie, S. M., Lee, J., \& Podsakoff, N. P. (2003). Common method variance in behavioral research: A critical review of the literature and recommended remedies. Journal of Applied Psychology, 88, 879-903. http://dx.doi.org/10.1037/0021-9010.88.5.879

Quick, J. C. (2004). Behind the mask coaching through deep interpersonal communication. Consulting Psychology Journal: Practice and Research, 56(2), 67-74. http://dx.doi.org/10.1037/1061-4087.56.2.67

Redshaw, B. (2000). Do we really understand coaching? How can we make it better? Industrial and commercial Training, 32(3), 106-108. http://dx.doi.org/10.1108/00197850010371693

Rhoades, L., \& Eisenberger, R. (2002). Perceived organizational support: A review of the literature. Journal of Applied Psychology, 87(4), 698-714. http://dx.doi.org/10.1037/0021-9010.87.4.698

Rusbult, C. E., \& Farrell, D. (1983). A longitudinal test of the investment model: The impact on job satisfaction, job commitment, and turnover of variations in rewards, costs, alternatives, and investments. Journal of Applied Psychology, 68(3), 429-438. http://dx.doi.org/10.1037/0021-9010.68.3.429 
Schein, E. H. (1996). Career anchors revisited: Implications for career development in the $21^{\text {st }}$ century. Academy of Management Executive, 80-88.

Shore, L. M., \& Wayne, S. J. (1993). Commitment and employee behavior: comparison of affective commitment and continuance commitment with perceived organizational support. Journal of Applied Psychology, 78(5), 774-780. http://dx.doi.org/10.1037/0021-9010.78.5.774

Sicherman, N., \& Galor, O. (1990). A theory of career mobility. The Journal of Political Ecomomy, 98(1), 169-192. http://dx.doi.org/10.1086/261674

Slater, S. F., \& Narver, J. C. (1995). Market orientation and the learning organization. The Journal of Marketing, 59(3), 63-74. http://dx.doi.org/10.2307/1252120

Stassen, A. M. (2004). The influence of prior commitment on the reactions of layoff survivors to organizational downsizing. Journal of Occupational Health Psychology, 9(1), 46-60. http://dx.doi.org/10.1037/1076-8998.9.1.46

Stowell, S. J. (1988). Coaching: A commitment to leadership. Training and Development Journal, 42(6), 34-38.

Stryker, S. (1980). Symbolic interactionism: A Social Structure Version. Palo Alto, CA: Benjamin Cummings.

Stryker, S., \& Serpe, R. (1994). Identity salience and psychological centrality: Equivalent, overlapping, or complementary concepts? Social Psychology Quarterly, 57(1), 16-35. http://dx.doi.org/10.2307/2786972

Tansky, J. W., \& Cohen, D. J. (2001). The relationship between organizational support, employee development and organizational commitment: An empirical study. Human Resource Development Quarterly, 12(3), 285-300. http://dx.doi.org/10.1002/hrdq.15

Vries, M. K., Guillén L., Korotov, K., \& Treacy, E. F. (2010). The coaching kaleidoscope: Insights from inside. Great Britain: Palgrave Macmillan. http://dx.doi.org/10.1057/9780230281790

Webber, A. M. (1993). What's so new about the new economy? Harvard Business Review, 71, 24-42.

White, B. (1995). The career development of successful women. Women in Management Review, 10(3), 4-15. http://dx.doi.org/10.1108/09649429510085053

Wilson, M. G., Dejoy, D. M., Vandenberg, R. J., Richardson, H. A., \& McGrath, A. L. (2004). Work characteristics and employee health and well-being: Test of a model of healthy work organization. Journal of Occupational and Organizational Psychology, 77(4), 565-588. http://dx.doi.org/10.1348/0963179042596522

Yarnall, J. (1998). Line manager as career developer: Rhetoric or reality? Personnel Review, 27(5), 378-395. http://dx.doi.org/10.1108/00483489810230325

Yoon, J. (2000). Supervisor support in the work place: Legitimacy and positive affectivity. Journal of Social Psychology, 140(3), 295-316. http://dx.doi.org/10.1080/00224540009600472

Young, R. A., Valach, L., \& Collin, A. (2002). From a contextualist explanation of career. In D. Brown, \& Associated (Eds.), Career Choice and Development (pp. 206-254). CA: Jossey-Bass.

Yukl, G. (1989). Managerial leadership: A review of theory and research. Journal of management, 15, 251-289. http://dx.doi.org/10.1177/014920638901500207

Yukl, G. (1994). Leadership in organizations (3rd ed.). Englewood Cliffs, NJ: Prentice-Hall.

Zientek, L. R., \& Thompson, B. (2009). Matrix summaries improve research reports: Secondary analyses using published literature. Educational Researcher, 38, 343-352. http://dx.doi.org/10.3102/0013189X09339056

\section{Copyrights}

Copyright for this article is retained by the author(s), with first publication rights granted to the journal.

This is an open-access article distributed under the terms and conditions of the Creative Commons Attribution license (http://creativecommons.org/licenses/by/3.0/). 